\title{
Research on the Mechanism and Method of China's Multi-year Budget Balance
}

\author{
Li Yan ${ }^{1}$ \\ Yunnan University of Finance and \\ Economics,Kunming,Yunnan,China \\ lhzly911129@163.com.
}

\begin{abstract}
The government budget management mainly has three goals: financial discipline, resource priority allocation and execution performance. However, the annual budget balance is not very good to achieve the three objectives of the budget management. The important aspect of China's budget reform is how to achieve multi-year budget balance, and to establish the multi-year budget balancing mechanism. In this paper, the description of budget is the government budget, and we hope to establish a reference basis for the realization of the multi-year budget balancing mechanism through the research on multi-year budget balancing under the government's medium-term fiscal planning.
\end{abstract}

\section{Keywords-Budget, The multi-year budget, Balance, Annual budget}

\section{THE DEVELOPMENT OF THE INTER ANNUAL BUDGET IN} CHINA

Since 1994, China began a series of fiscal reform, opening the macro process of the establishment of a modern financial system. Following the establishment of a modern financial system in the third Plenary Session of the $18^{\text {th }} \mathrm{CPC}$ Central Committee, the finance and tax system have been introduced in order to speed up the reform of the budget management system, and deal with a series of problems about the annual budget, for example, cleaning up the standard tax, strengthen local government debt management and so on. Those policies show that China's fiscal and tax reform has entered a stage of comprehensive deepening, and the foundation and pillar of the financial function have become increasingly prominent.

In November 2008, "Interim rolling budget framework seminar" held in the Ministry of finance budget Secretary. At the meeting, the establishment of inter annual budget balance mechanism and other issues were discussed. In November 2013, "Improved budget management system" was put forward in the party's the third Plenary Session of the $18^{\text {th }}$ CPC Central Committee. In August 2014, after the revised budget law of the people's Republic of China adopted, government stipulate to establish the inter annual budget balance mechanism clearly. At the beginning of the

\author{
Peng Chao ${ }^{2}$ \\ Central University of Finance and Economics,Beijing,China \\ pcslz@163.com.
}

year of 2015, in order to solve the problems existing in China's annual budget management system and clear reform objectives, The advice about the interim financial planning and management was issued by the State Council, which make clear to accelerate the establishment of a modern financial system and improve the budget management.

\section{THE CHALLENGE OF CHINA TO ESTABLISH THE MULTI-YEAR BUDGET BALANCING MECHANISM}

\section{A.Dealing with its connection with the annual budget well}

At present, the multi-year budget in China is the layout of continuous budgeting of three years and it gets updated every year. It focuses on predicting and adapting the financial revenue and expenditure according to the changes of policies and it possesses great macrocosm and expectedness and can deal with the problems brought by annual budget balance, but it does not mean to replace annual budget. The budget layout of the first year in the multi-year budget is the government budget that year and it has strong restriction, and the budget of the second and the third year is the annual budget of the following two year and has expectedness and guidance. The total expenditure of annual budget and the upper control limit of department cannot breakthrough the control objective determined by the layout of the multi-year budget. How to deal with the relationship between the multi-year budget and annual budget and how to make the transition from annual budget to the multi-year budget including annual budget is one of the problem that is urgent to be solved.

\section{B. Dealing with its connection with the national economic and social development well}

In actual operations, it is a little difficult to connect the national economic and social development with budget. Firstly, in the aspect the time, the multi-year budget balancing mechanism requires the Office of Management of the Budget to arrange the budgetary fund centering on the national medium and long-term strategic plan fully to affirm the continuity of fiscal policy, but the national economic and social development plan made over a five-year period is inconsistent with the multi-year budget balancing 
mechanism made over a three-year period in time. It is quite difficult to combine them in terms of the compatibility of policy program. Secondly, from the content, the national economic and social development plan has the characteristic of rough outline, and it does not provide detailed quantification of fiscal expenditure. What's more, some economic fluctuations are sudden, which is not in accordance with the objective of the exact forecast of revenue and expenditure of the multi-year budget. As a result, in dealing with the connection between the multi-year budget with national economic and social development plan, great importance should be laid on the co-movement of economy, policies and projects to avoid the conflicts between the two and realize the perfect connection between them.

\section{Dealing with the accuracy of budget revenue and expenditure forecast well}

After the establishment of the multi-year budget balancing mechanism, budget revenue has both disciplinary and expectedness and it transits from task number to forecasting number, as a result, the accurate forecast is the core step of the successful realization of multi-year budget balance. From the perspective of effects, for a country with little fluctuations in policy and little fluctuation range of market economy, it is relatively less hard to forecast its financial revenue and expenditure and there are little forecasting errors. However, in China, the economic growth presents an declining trend, the adjustment of industrial structure has not been accomplished, there are still many serious problems in secondary industry, the market oriented economy is not mature enough. In particular, this year is the beginning of the implementation of the spirit of $19^{\text {th }} \mathrm{CPC}$ National Congress of the Party, the 40th anniversary of reform and opening up, and the crucial year of decisive success in building a well-off society in an all-round way and carrying out the 13th Five-Year Plan. All those problems make it more difficult to forecast the future budgetary revenues and expenditures.

\section{TO ESTABLISH THE MULTI-YEAR BUDGET BALANCING MECHANISM}

\section{A.Preparation the multi-year budget}

Preparation the multi-year budget is conducive to the realization of medium-term fiscal planning, the rational determination and effective implementation of medium-term fiscal policy, and the allocation of the optimization.

First of all, the establishment of a scientific model of revenue and expenditure forecast. For budget revenue, it transits from task number to forecasting number and has expectedness and guidance. Date related to tax revenue should be comprehensive, realistic and accurate, and they should be given full consideration with the economic development situation, tax elasticity, policy adjustment and other factors. After reasonable analysis of the impact of those factors, government should select scientific and reasonable forecast model to forecast all kinds of taxes. For nontax revenue, considering its particularity, government should select scientific forecast model with different characteristics. For budget expenditure, according to the adaption of property and administrative power, government should to further clarify the boundary between government and market, such as the public product scale which is provided by government.

Secondly, the establishment of medium and long-term projects' reserve bank. Combining with the four principles, government should submit feasibility analysis of the projects, including analysis of cost effectiveness, social effects and environmental effect and so on. After those projects pass review, they can be included in the management and supervision of the multi-year budget reserve bank.

At last, the perfection of the budget stabilization fund. The multi-year budget balance is not limited to the balance of payments in a single year, and for the multi-year budget balance, the core idea is that the expenditure budget is determined by the expenditure policy. Under the multi-year budget balancing mechanism, revenue and expenditure do not match in the first year of the budget cycle. In order to prevent the occurrence of this situation, government should to improve the stability of budget stabilization fund. When financial revenue excesses financial expenditure, the financial surplus can be used for the next year to expand the financial resources available or to resolve government debt; when financial expenditure excesses financial revenue, government should pay more attention about future budget forecast and arrangement. After that, budget balance will achieve long-term dynamic balance.

\section{B. Other supporting mechanisms}

Establishing a scientific mechanism for the medium and long projects. Generally speaking, it is complex and strict for the expenditure arrangements of the medium and long major projects, so it needs to maintain continuity and consistency. Under the requirement of "micro release, macro control", government should grasp the accuracy of the forecast date in order to get the effective connection between the expenditure policy and the choice of major projects.

Establishing mechanism for the whole process of performance management. Taking the horizontal adjustment 
and vertical penetration, government should further promote the performance management mechanism of multi-year budget balance through the improvement of department of the budget, strengthen the budget execution and so on.

Establishing mechanism for government and social capital cooperation (PPP model). Government should encourage social capital fair competition, use of franchising to investment and operation of public service project. It can reduce the pressure on government investment spending and debt, conducive to the realization of the goal of multi-year budget and establish the multi-year budget balancing mechanism. For those reason, the government should clear the main responsibility of PPP executive institution, budget department allocate funds strictly according to the contract of the project budget, and the competent authorities and the financial sector to supervise their rectification work. Among them, according to the characteristics of the projects, the budget department should focus on different types of PPP projects through research, planning, evaluation, construction and operation, to ensure the project schedule, quality and quantity. In addition, in the selection of PPP projects, special attention should be paid to avoid the project which paid by the government in the end.

\section{REFERENCES}

[1]Li Ciqiang . (2015) The Balance Mechanism and Construction of Inter Annual Budget. Studies in Law and Business, 1, 29-33.(In Chinese)

[2]Xie Lin .(2015) The Introduction of Medium-term Basic Budget: Review and Prospect of the Process. Local Financial Research, 3, 13-23.(In Chinese)

[3]Kou Mingfeng . (2015) Medium-term Budget: Technical Problems and Institutional Difficulties. Local Financial Research.(In Chinese)

[4]Li Yan . (2012) Fiscal Sustainability and the Medium Term Fiscal Inquiry in the Perspective of Transparency. Administrative Management in China, 9, 43-46.(In Chinese)

[5]Bai Yanfeng . (2014) "Stable Tax Burden" and the Reform of Medium-term Fiscal Planning and Management. China Finance, 664, 18-20.(In Chinese)

[6]Yang Zhiyong . (2014) China's Medium-term Fiscal Planning Reform: the Basic Direction and Main Problems. China Finance, 11, 15-17. (In Chinese)

[7]Wang. Zhigang. (2014) Thoughts on the Establishment of the Management System of Medium-term Financial Planning. China Finance, 666, 44-46. (In Chinese) 